\title{
Effect of priming and seed-coating when associated with Bacillus subtilis in maize seeds ${ }^{1}$
}

\author{
Efeito do condicionamento fisiológico e da peliculização associados à Bacillus \\ subtilis em sementes de milho
}

Emanuele Junges ${ }^{2 *}$, Marcos Toebe ${ }^{3}$, Ricardo Feliciano dos Santos ${ }^{4}$, Geísa Finger ${ }^{5}$ e Marlove Fátima Brião Muniz

\begin{abstract}
The aim of this study was to evaluate the effect on the physiological performance of maize seeds (Zea mays L.) of micro-priming with Bacillus subtilis associated with techniques of water restriction and seed-coating. The micro-priming of the seeds, without any additional techniques, was carried out using a commercial product, Rhizoliptus ${ }^{\circledR}$ (Bacillus subtilis). Water restriction was carried out using a PDA medium (Potato - Dextrose - Agar) with mannitol (-0.7 MPa), upon which the culture was grown for 48 hours. One hundred sterilized corn seeds were placed in each dish. Once root protrusion occurred in one seed, the rest were removed and kept in a laboratory environment for 48 hours. The coating was carried out by the addition of Seed Polymer Color HE (50 ml kg ${ }^{-1}$ ) to the priming mixture containing the Bacillus subtilis. The seeds were kept for 48 hours in a laboratory environment. A treatment which associated seed coating and water restriction was used on the micro-primed seeds, together with a control treatment without the addition of Bacillus subtilis. The Bacillus subtilis has no effect on the health of the seeds it; does however contribute to the growth and development of the maize seedlings, being influenced by the micropriming technique used. The use of water restriction associated with seed coating provides better results when micro-priming with Bacillus subtilis.
\end{abstract}

Key words: Polymer. Priming. Initial growth and development. Zea mays L.

RESUMO - O objetivo deste trabalho foi avaliar o efeito da microbiolização de sementes com Bacillus subtilis, associada às técnicas de restrição hídrica e peliculização sobre o desempenho fisiológico de sementes de milho (Zea mays L.). A microbiolização das sementes sem técnica adicional foi realizada com o produto comercial Rhizoliptus ${ }^{\circledR}$ (Bacillus subtilis). A restrição hídrica foi realizada em meio BDA (Batata - Dextrose - Ágar) + manitol (-0,7 MPa), sobre o qual a bactéria foi cultivada por 48 h. Foram distribuídas 100 sementes de milho desinfestadas em cada placa. Quando houve protrusão radicular na primeira semente, as demais foram retiradas e mantidas em ambiente de laboratório por $48 \mathrm{~h}$. A peliculização foi realizada com a adição do polímero Color Seed $\mathrm{HE}\left(50 \mathrm{~mL} \mathrm{~kg}^{-1}\right)$ à calda de tratamento contendo Bacillus subtilis. As sementes foram mantidas por $48 \mathrm{~h}$ em ambiente de laboratório. Foi utilizado um tratamento associando a peliculização e a restrição hídrica nas sementes microbiolizadas e ainda, um tratamento testemunha, sem adição de Bacillus subtilis. Bacillus subtilis não apresenta efeito sobre a sanidade de sementes, entretanto, contribui para o crescimento e desenvolvimento de plântulas de milho, sendo influenciado pela técnica de microbiolização utilizada. A associação da restrição hídrica com a peliculização proporciona melhor desempenho no efeito da microbiolização com Bacillus subtilis.

Palavras-chave: Polímero. Condicionamento fisiológico. Crescimento e desenvolvimento inicial. Zea mays L..

\footnotetext{
* Autor para correspondência

${ }^{1}$ Recebido para publicação em 16/10/2011; aprovado em 26/12/2012

Parte da Dissertação de Mestrado do primeiro autor apresentada ao Programa de Pós-Graduação em Agronomia da Universidade Federal de Santa Maria/UFSM

${ }^{2}$ Universidade Federal de Santa Maria, Santa Maria-RS, Brasil, manujunges@yahoo.com.br

${ }^{3}$ Bolsista do CNPQ, Programa de Pós-Graduação em Agronomia, Universidade Federal de Santa Maria, Santa Maria-RS, Brasil, m.toebe@gmail.com ${ }^{4}$ Programa de Pós-Graduação em Agronomia da Universidade Federal de Santa Maria com ênfase em Proteção de Plantas Cultivadas/Fitopatologia, Santa Maria-RS, Brasil, ricardoijui@hotmail.com

${ }^{5}$ Graduada em Agronomia, Departamento de Defesa Fitossanitária, Universidade Federal de Santa Maria, Santa Maria-RS, Brasil, ge_finger@ yahoo.com.br

${ }^{6}$ Departamento de Defesa Fitossanitária, Centro de Ciências Rurais, Universidade Federal de Santa Maria, Santa Maria-RS, Brasil, marlove@pq.cnpq.br
} 


\section{INTRODUCTION}

The treatment of seeds is important to ensure the health of those seeds and the seedlings they generate, allowing full expression of the genetic and physiological potential of the crop. Micro-priming is a technique which aims to cover the seeds with living organisms to act in biocontrol and/or growth promotion (MELO, 1996). Among the most studied genera of rhizobacteria which promote growth, those that stand out are: Bacillus, Pseudomonas, Azospirillum and rhizobia (ARAUJO, 2008).

Bacillus subtilis is a rhizobacterium to which is attributed the synthesis of phytohormones, such as indoleacetic acid, abscisic acid, gibberellins and cytokinins, which favour root growth and an increase in the number of root hairs (ARAUJO, HUNGARY, 1999). The inoculation of maize seeds with Bacillus subtilis and oyster meal contributed to the growth, development and nutrition of the plants (ARAUJO, 2008; ARAUJO, WARRIOR, 2010). Araujo (2008) also shows that formulation has significant value in determining the end-efficacy of a product based on those rhizobacteria which promote plant growth.

Priming (water restriction, osmotic conditioning, or hydro conditioning) has been used to improve the performance of the seeds from different plant species (HOLBIG et al., 2010; HOLBIG; BAUDET; VILLELA, 2011). In addition, priming has been used in studies aimed at obtaining different levels of pathogen infection in seeds without compromising their characteristics for germination (DEUNER et al., 2011; SOUSA et al., 2008).

In the seed of the sweet corn, osmotic conditioning promoted an increase in the percentage and speed of germination (OLIVEIRA et al., 2007). Further, the combination of osmotic conditioning with micropriming can promote a synergy of the benefits from both techniques. To this effect, Andreoli and Andrade (2003) found that integrating matrix conditioning with biological treatments (Bacillus) was effective in increasing the vigour of lower quality maize seeds.

To improve performance and add value to the seeds, use is also made of techniques of improvement, such as coating with film. Coating provides, among other benefits, excellent adhesion, favouring the addition of agricultural additives (SILVA, SANTOS; BIRTH, 2002), without altering the size or shape of the seeds, and protecting them from attack by pathogens (DINIZ et al., 2006).

Corn crops are highly responsive to fertilization, and therefore conditioning techniques that allow the rapid development of the seedlings and their non- dependence on seed reserves, become even more important. The present study therefore, aimed to evaluate micro-priming with Bacillus subtilis when associated with physiological conditioning and film coating, on the health, germination and vigour of maize seeds.

\section{MATERIAL AND METHODS}

An experiment was conducted in 2010 at the Laboratory of Plant Pathology, and in the greenhouses of the Department of Plant-Health Protection of the Federal University of Santa Maria, in Santa Maria, Rio Grande do Sul (latitude $29^{\circ} 42^{\prime}$ S, longitude 53⒋' W, at an altitude of $95 \mathrm{~m}$ ). In this experiment, open-pollinated maize seeds of the "Sertanejo"variety were used, coming from the seed bank of the Associação dos Agricultores Guardiões de Semente de Milho Crioulo, in the town of Ibarama, Rio Grande do Sul. Using these seeds, methods of micro-priming (water restriction and film coating) were evaluated for the commercial biological product Rhizoliptus $®$, which is based on the bacterial agent Bacillus subtilis.

Initially, a preliminary trial was carried out to determine the optimum water potential for priming maize seeds in a culture medium of PDA (potato dextrose and agar) supplemented with mannitol solute. The culture medium at different strengths $(0.0 ;-0.6 ;-0.7 ;-0.8$ and -0.9 MPa) was placed into Petri dishes in accordance with Coutinho et al. (2001), on which were then placed 100 previously sterilized maize seeds. The seeds were incubated in a growth chamber, with a photo period of 12 hours at $25{ }^{\circ} \mathrm{C}$ until root protrusion occurred in the first seed. All the seeds were then removed and kept in a laboratory environment for $48 \mathrm{~h}$, when the test for germination on paper rolls was set up. For each strength tested, 200 seeds were used, divided into eight replications of 25 seeds. The rolls containing the seeds were kept for four days in a germinator at $25^{\circ} \mathrm{C}$ with a photo period of 12 hours, when the first count for germination was made, and also after seven days of incubation, the percentage of germination, abnormal seedlings and dead seeds was determined.

For the first treatment (T1) the commercial product Rhizoliptus $(\circledR$ was applied pure to previously sterilized seeds (1 mL/100 seeds). The seeds were packed into disposable plastic bags and homogenization carried out for 5 minutes. After micro-priming, the seeds were kept on filter paper under laboratory conditions for 48 hours.

For application of the treatment, $1 \mathrm{~mL}$ of the commercial product Rhizoliptus $₫$ was added to the PotatoDextrose-Agar (PDA) culture medium and supplemented with mannitol solute at $-0.7 \mathrm{MPa}$, which the preliminary 
trial had determined as giving the best performance for maize seeds. The dishes were incubated for 48 hours to allow for the growth and development of the bacteria on the medium. Then, 100 previously disinfected maize seeds were placed into each dish and incubated in a germinator, with a photoperiod of 12 hours at $25{ }^{\circ} \mathrm{C}$, until one seed showed early root protrusion, which occurred 72 hours after incubation. At this time, the remaining seeds were removed from the culture and kept on filter paper under laboratory conditions for 48 hours.

The third treatment (T3) consisted of micropriming with film coating. Collor Seed $₫$ He Red polymer was used, which was applied as recommended by the manufacturer: $50 \mathrm{~mL}$ of product for every $100 \mathrm{~kg}$ of seeds. The spray was prepared by adding an amount of polymer relative to the weight of the sample, and $1 \mathrm{ml}$ of the product containing Bacillus subtilis, for every 100 seeds. After micro-priming, the seeds were kept on filter paper under laboratory conditions for 48 hours.

The fourth treatment (T4) consisted of micropriming, carried out by water restriction as described above, and then keeping the seeds on filter paper under ambient conditions for 48 hours. They were then subjected to film coating, following the manufacturer's recommendations, once again remaining at ambient temperature on filter paper for 48 hours.

The control (T5) consisted of seeds disinfected in a solution of $1 \%$ sodium hypochlorite for one minute, followed by alcohol at $70 \%$ for one minute and three washes in sterile distilled water. The seeds were immediately placed onto filter paper and kept in a laboratory environment for 48 hours.

To evaluate the performance of the seeds subjected to the different treatments, evaluations were made of the health, germination, cold test, growth and development of the seedlings, both in trays and in plots, and the speed of emergence index measured. For the health evaluation, 200 seeds were used per treatment, divided into eight replications of 25 seeds. These seeds were placed in germination boxes which had been previously sterilized with $70 \%$ alcohol and sodium hypochlorite at $1 \%$, containing two sheets of sterile filter paper, soaked with $2.4-\mathrm{Da} 0.5 \%$ to inhibit germination. After this procedure, the seeds were incubated at $25^{\circ} \mathrm{C}$, with a photo period of 12 hours for five days, and analysed with the aid of a stereoscopic and optical microscope, in order to see the morphological structures of the fungi, which were identified as to genus with the aid of a specialized bibliography (BARNET; HUNTER, 1972), the percentage incidence of each fungal genus being determined.

For the measurement of the variables related to germination, 200 seeds were used for each treatment, divided into eight replications of 25 seeds, placed on rolls of filter paper moistened with distilled water at a ratio of 2.5 times the dry weight of the paper. The rolls containing the seeds were kept in a germinator set for a temperature of $25^{\circ} \mathrm{C}$ and photo period of 12 hours. Two counts were made, at four and seven days, according to the Rules for Seed Analysis (BRAZIL, 2009), the first count was of normal seedlings from each replication, where ten seedlings were randomly selected, and the length of shoot and root measured and summed to give the total length. Due to the reduced mass, the seedlings were grouped into four replications in order to determine dry weight, in a hothouse at $60{ }^{\circ} \mathrm{C}$ for 48 hours. After seven days of incubation, the seedlings were classified as normal strong, normal weak, abnormal and dead seeds, and the germination percentage for each treatment was obtained following the Rules for Seed Analysis (BRAZIL, 2009).

In the cold test, 200 seeds were used per treatment, divided into eight replications of 25 seeds, placed onto rolls of filter paper moistened with distilled water at a ratio of 2.5 times the dry weight of the paper. The seeds remained in a refrigerator at $10{ }^{\circ} \mathrm{C}$ for five days and were then incubated in germinators under the conditions of the germination test, in accordance with Molina, Irigon and Zonta (1987).

Four replications of five seeds for each treatment were sown in trays containing commercial substrate. The trays were kept in a greenhouse and irrigated as needed. Four replications of 10 seeds for each treatment were sown in beds of turned soil in a greenhouse. Daily counts were taken of the emerged seedlings in the trays and the beds, until reaching a constant number, and for each repetition, the speed of emergence index was then calculated by summing the number of emerged plants each day, divided by the respective number of days elapsed since sowing, according to Maguire (1962). At 10 days after sowing, the number of emerged plants was counted, and based on these, the average number of leaves, average diameter of the stem, average height and average dry weight of the shoot for each seedling from the beds and trays were calculated.

For each variable a variance analysis was performed using the $\mathrm{F}$ test at $5 \%$ significance, and the differences between averages were compared by the Scott-Knott test at 5\% significance, using the statistical application GENES (CRUZ, 2006).

\section{RESULTS AND DISCUSSION}

Mannitol strengths of $-0.6,-0.7,-0.8$ and -0.9 $\mathrm{MPa}$ were all similar and higher than the control $(0.0$ $\mathrm{MPa}$ ) for the first count of germination and the number 
of germinated seeds, and had fewer abnormal seedlings (Table 1). However, the smallest number of dead seeds occurred at a strength of $0.7 \mathrm{MPa}$, despite not differing from the higher strengths and from the control. Due to the increased performance provided by the negative strengths in relation to the control and the lowest number of dead seeds, a strength of $-0.7 \mathrm{MPa}$ in the PDA culture medium was determined as being ideal for the osmotic conditioning of maize seed and the subsequent application of treatments with micro-priming.

Bacillus subtilis was not effective in controlling pathogens associated with maize seeds, and in some treatments there was an increased incidence of Fusarium spp. and Penicillium spp. (Table 2). The treatment with water restriction, favoured the incidence of Trichoderma spp. which may be beneficial, as this fungus can act in controlling pathogens in seeds and subsequently in the ground. However, water restriction and film coating favoured the incidence of Fusarium spp, and the combination of these techniques reduced the incidence of
Trichoderma spp. and Fusarium spp., reducing competition and increasing the incidence of Penicillium spp.

The inefficiency of Bacillus subtilis on the pathogens associated with the seeds may be due to the short time of contact between the organisms, there not having been time for direct biocontrol action. A different response is expected during the crop cycle, when the application of Bacillus subtilis to the soil or via seed may provide disease control in the shoot by inducing resistance. To this effect, Araujo and Menezes (2009) verified the control of diseases in tomato shoots as having an efficiency similar to that of chemical fungicides. Isolated Bacillus spp. was reported as having the control potential of scalding in rice (Gerlachia oryzae) through the micro-priming of seeds (LUDWIG et al., 2009) and control of fungi transmitted by oat seeds (SILVA et al., 2002).

The effect of seed inoculation with Bacillus subtilis in the trials to evaluate the physiological quality of the seeds, showed a reduction, at the first count for

Table 1 - Mean values of the evaluation of germination first count (GFC), germinated seeds (GER), dead seeds (DES) and abnormal seedlings (ABS) in physiologically primed seeds in a PDA culture medium supplemented with mannitol solute at different strengths

\begin{tabular}{lcccc}
\hline $\begin{array}{c}\text { Treatment } \\
(\mathrm{MPa})\end{array}$ & GFC & GER & DES & ABS \\
\hline 0.0 & $\%$ & $\%$ & $\%$ & $\%$ \\
-0.6 & $10.00 \mathrm{~b}^{(1)}$ & $52.50 \mathrm{~b}$ & $12.00 \mathrm{a}$ & $27.50 \mathrm{a}$ \\
-0.7 & $18.75 \mathrm{a}$ & $72.00 \mathrm{a}$ & $13.50 \mathrm{a}$ & $11.00 \mathrm{~b}$ \\
-0.8 & $18.25 \mathrm{a}$ & $78.50 \mathrm{a}$ & $05.50 \mathrm{a}$ & $11.50 \mathrm{~b}$ \\
-0.9 & $18.75 \mathrm{a}$ & $78.00 \mathrm{a}$ & $08.00 \mathrm{a}$ & $09.00 \mathrm{~b}$ \\
\hline $\mathrm{CV} \%$ & $18.00 \mathrm{a}$ & $76.50 \mathrm{a}$ & $08.50 \mathrm{a}$ & $10.50 \mathrm{~b}$ \\
\hline
\end{tabular}

${ }^{(1)}$ Means with same letter in any one column do not differ by the Scott-Knott test at $5 \%$ significance

Table 2 - Averages of the data relating to the health of maize seeds submitted to different treatments

\begin{tabular}{|c|c|c|c|}
\hline Treatment ${ }^{(1)}$ & $\begin{array}{c}\text { Trichoderma spp. } \\
\%\end{array}$ & $\begin{array}{c}\text { Fusarium spp. } \\
\%\end{array}$ & $\begin{array}{c}\text { Penicillium spp. } \\
\%\end{array}$ \\
\hline $\mathrm{T} 1$ & $2.00 \mathrm{~b}^{(3)}$ & $24.00 \mathrm{~b}$ & $42.50 \mathrm{~b}$ \\
\hline $\mathrm{T} 2$ & $16.00 \mathrm{a}$ & $51.50 \mathrm{a}$ & $37.00 \mathrm{~b}$ \\
\hline $\mathrm{T} 3$ & $1.00 \mathrm{~b}$ & $43.50 \mathrm{a}$ & $43.50 \mathrm{~b}$ \\
\hline $\mathrm{T} 4$ & $0.00 \mathrm{~b}$ & $19.50 \mathrm{~b}$ & $100.00 \mathrm{a}$ \\
\hline $\mathrm{T} 5$ & $1.50 \mathrm{~b}$ & $25.50 \mathrm{~b}$ & $30.00 \mathrm{~b}$ \\
\hline $\mathrm{Fc}^{(2)}$ & $13.20 *$ & $7.99 *$ & $49.07 *$ \\
\hline $\mathrm{CV}(\%)$ & 127.07 & 42.37 & 22.45 \\
\hline
\end{tabular}


germination, in the percentage of strong seedlings, and an increase in the percentage of weak seedlings and dead seeds (Table 3). However, the treatments did not affect seed germination under those conditions ideal for the growth of microorganisms. Mafia et al. (2009) observed an increase in the percentage of seed germination in Eucalyptus spp., and Silva et al. (2002) obtained a larger amount of emerged oat seedlings when the seeds had been micro-primed with Bacillus subtilis.

The use of micro-priming techniques with Bacillus subtilis on seeds demonstrated the action of bacteria as promoting growth in maize seedlings, producing seedlings with greater shoot length, root length, and total length (Table 4). This effect on maize seedlings may be due to the action of Bacillus subtilis as an inducer of phytohormones, such as indoleacetic acid, abscisic acid, gibberellins and cytokinins which favour root growth and an increase in the number of root hairs (ARAUJO, HUNGARY, 1999). The highest values were seen with the use of film coating alone, and when combined with water restriction. Those seeds subjected to water restriction displayed greater seedling length, being superior to the traditional method of micro-priming.

Table 3 - Average values for germination (GER), germination first count (GFC), strong seedlings (STS), weak seedlings (WKS), abnormal seedlings (ABS) and dead seeds (DES) for maize seeds submitted to different treatments

\begin{tabular}{lcccccc}
\hline \multirow{2}{*}{ Treatment $^{(1)}$} & GER & GFC & STS & WKS & ABS & DES \\
& $\%$ & $\%$ & $\%$ & $\%$ & $\%$ & $\%$ \\
\hline T1 & $79,75 \mathrm{a}^{(3)}$ & $50,50 \mathrm{~b}$ & $69,00 \mathrm{~b}$ & $11,50 \mathrm{a}$ & $10,50 \mathrm{a}$ & $9,00 \mathrm{~b}$ \\
$\mathrm{~T} 2$ & $74,00 \mathrm{a}$ & $51,50 \mathrm{~b}$ & $65,50 \mathrm{~b}$ & $8,50 \mathrm{a}$ & $11,50 \mathrm{a}$ & $14,50 \mathrm{a}$ \\
$\mathrm{T} 3$ & $82,00 \mathrm{a}$ & $74,50 \mathrm{a}$ & $81,50 \mathrm{a}$ & $0,50 \mathrm{~b}$ & $2,50 \mathrm{~b}$ & $15,50 \mathrm{a}$ \\
$\mathrm{T} 4$ & $74,00 \mathrm{a}$ & $66,00 \mathrm{a}$ & $69,50 \mathrm{~b}$ & $4,50 \mathrm{~b}$ & $5,00 \mathrm{~b}$ & $21,00 \mathrm{a}$ \\
$\mathrm{T} 5$ & $81,00 \mathrm{a}$ & $62,50 \mathrm{a}$ & $76,50 \mathrm{a}$ & $4,50 \mathrm{~b}$ & $10,50 \mathrm{a}$ & $8,50 \mathrm{~b}$ \\
\hline $\mathrm{Fc}^{(2)}$ & $1,44^{\text {ns }}$ & $6,13^{*}$ & $2,98^{*}$ & $3,37 *$ & $4,93 *$ & $4,72^{*}$ \\
$\mathrm{CV}(\%)$ & 11,66 & 18,96 & 17,71 & 110,14 & 67,61 & 49,01 \\
\hline
\end{tabular}

${ }^{(1)}$ Treatments: $\mathrm{T} 1$ = Application of Bacillus subtilis; $\mathrm{T} 2$ = Application of Bacillus subtilis with fluid restriction; T3 = Application of Bacillus subtilis with film coating; $\mathrm{T} 4$ = Application of Bacillus subtilis with water restriction and film coating; T5 = Control without the application of Bacillus subtilis, water restriction or film coating; ${ }^{(2)}$ Significant effect by the $\mathrm{F}$ testa t a $5 \%$ level of significance. ${ }^{\text {ns }}$ Not significant; ${ }^{(3)}$ Means with same letter in any one column do not differ by the Scott-Knott test at $5 \%$ significance

Table 4 - Average length of shoots (LSH), root length (LRO), total length (TOL), average dry weight of seedling shoots (SDW), mean seedling root dry weight (RDW), mean seedling total dry weight (TDW), average emergence of plant in trays (PET), average number of leaves of bedded plants (NLB) and speed of emergence index (SEI) in maize seeds submitted to different treatments

\begin{tabular}{|c|c|c|c|c|c|c|c|c|c|}
\hline Treatment $^{(1)}$ & $\begin{array}{c}\text { LSH } \\
\mathrm{cm}\end{array}$ & $\begin{array}{c}\text { LRO } \\
\mathrm{cm}\end{array}$ & $\begin{array}{c}\text { TOL } \\
\mathrm{cm}\end{array}$ & $\begin{array}{c}\text { SDW } \\
\text { mg }\end{array}$ & $\begin{array}{c}\text { RDW } \\
\text { mg }\end{array}$ & $\begin{array}{c}\text { TDW } \\
\text { mg }\end{array}$ & $\begin{array}{c}\text { PET } \\
\%\end{array}$ & $\begin{array}{c}\text { NLB } \\
\text { un }\end{array}$ & $\begin{array}{c}\text { SEI } \\
-\end{array}$ \\
\hline $\mathrm{T} 1$ & $2.55 c^{(3)}$ & $4.89 \mathrm{c}$ & $7.44 \mathrm{c}$ & $0.85 \mathrm{c}$ & $1.25 \mathrm{c}$ & $2.11 \mathrm{c}$ & $65.00 \mathrm{a}$ & $5.08 \mathrm{~b}$ & $43.26 \mathrm{~b}$ \\
\hline $\mathrm{T} 2$ & $2.93 \mathrm{~b}$ & $6.54 \mathrm{~b}$ & $9.47 \mathrm{~b}$ & $1.18 \mathrm{~b}$ & $1.60 \mathrm{~b}$ & $2.78 \mathrm{~b}$ & $45.00 \mathrm{~b}$ & $5.72 \mathrm{a}$ & $51.65 \mathrm{a}$ \\
\hline $\mathrm{T} 3$ & $3.71 \mathrm{a}$ & $7.42 \mathrm{a}$ & $11.14 \mathrm{a}$ & $1.21 \mathrm{~b}$ & $1.51 \mathrm{~b}$ & $2.72 \mathrm{~b}$ & $85.00 \mathrm{a}$ & $4.91 \mathrm{~b}$ & $55.67 \mathrm{a}$ \\
\hline $\mathrm{T} 4$ & $4.04 \mathrm{a}$ & $8.01 \mathrm{a}$ & $12.06 \mathrm{a}$ & $1.51 \mathrm{a}$ & $1.81 \mathrm{a}$ & $3.32 \mathrm{a}$ & $80.00 \mathrm{a}$ & $5.37 \mathrm{a}$ & $61.80 \mathrm{a}$ \\
\hline $\mathrm{T} 5$ & $2.43 \mathrm{c}$ & $4.68 \mathrm{c}$ & $7.12 \mathrm{c}$ & $0.85 \mathrm{c}$ & $1.07 \mathrm{c}$ & $1.92 \mathrm{c}$ & $50.00 \mathrm{~b}$ & $4.88 \mathrm{~b}$ & $45.59 \mathrm{~b}$ \\
\hline $\mathrm{Fc}^{(2)}$ & $30.18 *$ & $19.03 *$ & $30.01 *$ & $23.06^{*}$ & $13.31 *$ & $35.14^{*}$ & $3.07 *$ & $4.01 *$ & $3.58 *$ \\
\hline $\mathrm{CV}(\%)$ & 11.70 & 15.28 & 11.94 & 10.29 & 10.96 & 7.36 & 31.02 & 6.75 & 15.41 \\
\hline
\end{tabular}

${ }^{(1)}$ Treatments: T1 = Application of Bacillus subtilis; $\mathrm{T} 2=$ Application of Bacillus subtilis with fluid restriction; T3 = Application of Bacillus subtilis with film coating; T4 = Application of Bacillus subtilis with water restriction and film coating; T5 = Control without the application of Bacillus subtilis, water restriction or film coating; ${ }^{(2)}$ Significant effect by the F testa t a $5 \%$ level of significance. ${ }^{\text {ns }}$ Not significant; ${ }^{(3)}$ Means with same letter in any one column do not differ by the Scott-Knott test at $5 \%$ significance 
The use of Bacillus subtilis promoted greater dry-matter accumulation that can be observed in the combination of water restriction and film coating, which separately performed badly. Correa, Bettiol and Sutton (2010) applying the formulation of Bacillus subtilis in nutrient solution to lettuce infected by Pythium spp., observed a greater accumulation of mass in the plants, and Mafia et al. (2007) and Mafia et al. (2009) verified a beneficial effect of Bacillus subtilis on the growth of plants of Eucalyptus spp. Araujo (2008) working with a formulation of Bacillus subtilis with oyster meal, saw greater growth and nutrition in maize, and Araujo and Marchesi (2009) observed greater growth and accumulation of mass in shoots of the tomato treated with Bacillus subtilis.

The application of Bacillus subtilis associated with water restriction (T2) and combined with film coating (T4) favoured the growth and development of seedlings, resulting in a greater number of leaves (Table 4). The increase in the speed of emergence index (SEI) was conditional on the adoption of micropriming techniques with water restriction and film coating, both isolated and in combination; when these techniques were not adopted, B. subtilis did not display its potential, being similar to the control. Andreoli and Andrade (2003), in trials with maize seeds primed in the presence of Bacillus subtilis, observed an increase in the SEI and in the percentage of seedling emergence at 10 days.

When evaluating the performance of the cold test, there was no difference between treatments, demonstrating that under conditions of physiological stress, seed performance is not influenced by Bacillus subtilis. The other variables: seedling emergence evaluated for bedded plants; height of seedlings evaluated for plants in trays and beds; number of leaves for seedlings in trays; average dry mass and average diameter of the plants evaluated in beds and trays, presented no significant differences between the treatments.

\section{CONCLUSIONS}

1. Bacillus subtilis has no effect on the health of maize seeds;

2. Bacillus subtilis promotes the growth and development of maize seedlings, being influenced by the micropriming technique used;

3. The association of water restriction with film coating provides better vigour in those seedlings, micro-primed with Bacillus subtilis.

\section{ACKNOWLEDGEMENT}

The authors wish to thank the Coordination for the Improvement of Higher Education Personnel - CAPES for the master's scholarship granted to the first author.

\section{REFERENCES}

ANDREOLI, C.; ANDRADE, R. V. de. Efeito do matricondicionamento integrado com controle químico e biológico na emergência de plântulas e na produtividade de milho. Revista Brasileira de Milho e Sorgo, v. 2, n. 3, p. 132-142, 2003.

ARAUJO, F. F. Inoculação de sementes com Bacillus subtilis, formulado com farinha de ostras e desenvolvimento de milho, soja e algodão. Ciência e Agrotecnologia, v. 32, n. 2, p. 456-462, 2008.

ARAUJO, F. F.; GUERREIRO, R. T. Bioprospecção de isolados de Bacillus promotores de crescimento de milho cultivado em solo autoclavado e natural. Ciência e Agrotecnologia, v. 34, n. 4, p. 837-844, 2010.

ARAUJO, F. F.; HUNGRIA, M. Nodulação e rendimento de soja co-infectada com Bacillus subtilis e Bradyrhizobium japonicum / Bradyrhizobium elkanii. Pesquisa Agropecuária Brasileira, v. 34, n. 9, p. 1633-1643, 1999.

ARAUJO, F. F.; MARCHESI, G. V. P. Uso de Bacillus subtilis no controle da meloidoginose e na promoção do crescimento do tomateiro. Ciência Rural, v. 39, n. 5, p. 1558-1561, 2009.

ARAUJO, F. F.; MENEZES, D. Indução de resistência a doenças foliares em tomateiro por indutores biótico (Bacillus subtilis) e abiótico (Acibenzolar-S-Metil). Summa phytopathologica, v. 35, n. 3, p. 169-172, 2009.

BARNET, H. L.; HUNTER, B. B. Ilustrated genera of imperfect fungi. 3. ed. Minneapolis: Burgess, 1972. 241 p.

BRASIL. Ministério da Agricultura e Reforma Agrária. Regras para análise de sementes. Brasília: SNDA/DNDV/CLAV, 2009. 398 p.

CORREA, É. B.; BetTIOL, W.; SUTTON, J. C. Controle biológico da podridão radicular (Pythium aphanidermatum) e promoção de crescimento por Pseudomonas chlororaphis 6328 e Bacillus subtilis GB03 em alface hidropônica. Summa phytopathologica, v. 36, n. 4, p. 275-281, 2010.

COUTINHO, W. M. et al. Uso da restrição hídrica na inibição ou retardamento da germinação de sementes de arroz e feijão submetidas ao teste de sanidade em meio ágar-água. Revista Brasileira de Sementes, v. 23, n. 2, p. 127-135, 2001.

CRUZ, C. D. Programa genes: estatística experimental e matrizes. Viçosa: UFV, 2006. 285 p.

DEUNER, C. C. et al. Inoculação de Curtobacterium flaccumfaciens pv. flaccumfaciens em sementes de feijão por meio da técnica de condicionamento fisiológico. Revista Brasileira de Sementes, v. 33, n. 1, p. 09-20, 2011. 
DINIZ, K. A. et al. Incorporação de microrganismos, aminoácidos, micronutrientes e reguladores de crescimento em sementes de alface pela técnica de peliculização. Revista Brasileira de Sementes, v. 28, n. 3, p. 37-43, 2006.

HOLBIG, L. S. et al. Recobrimento de sementes de cenoura osmocondicionadas. Revista Brasileira de Sementes, v. 32, n. 4 , p. $22-28,2010$.

HOLBIG, L. S.; BAUDET, L.; VILLELA, F. A. Hidrocondicionamento de sementes de cebola. Revista Brasileira de Sementes, v. 33, n. 1, p. 171-176, 2011.

LUDWIG, J. et al. Microbiolização de sementes para o controle da mancha-parda e da escaldadura em arroz irrigado. Tropical Plant Pathology, v. 34, n. 5, p. 322-328, 2009.

MAFIA, R. G. et al. Indução do enraizamento e crescimento do eucalipto por rizobactérias: efeito da adição de fonte alimentar e da composição do substrato de enraizamento. Revista Árvore, v. 31 , n. 4 , p. $589-597,2007$

MAFIA, R. G. et al. Root colonization and interaction among growth promoting rhizobacteria isolates and eucalypts species. Revista Árvore, v. 33, n. 1, p. 1-9, 2009.

MAGUIRE, J. D. Spead of germination-aid in selection and evaluation for seedling emergence and vigour. Crop Science, v. 2, n. 1, p. 176-177, 1962.
MELO, I. S. Trichoderma e Gliocladium como bioprotetores de plantas. Revisão Anual de Patologia de Plantas, v. 4, n. 1, p. 261-295, 1996.

MOLINA, J. C.; IRIGON, D. L.; ZONTA, E. P. Comparação entre metodologias do teste de frio na avaliação da qualidade fisiológica de sementes de milho (Zea mays L.). Revista Brasileira de Sementes, v. 9, n. 3, p. 77-85, 1987.

OLIVEIRA, A. S. et al. Condicionamento osmótico em sementes de milho doe submetidas ao armazenamento. Revista Ciência Agronômica, v. 38, n. 4, p. 444-448, 2007.

SILVA, J. B. C.; SANTOS, P. E. C.; NASCIMENTO, W. M. Desempenho de sementes peletizadas de alface em função do material cimentante e da temperatura de secagem dos péletes. Horticultura Brasileira, v. 20, n. 1, p. 67-70, 2002.

SILVA, R. T. V. et al. Efeito do tratamento de sementes e da profundidade de semeadura no desenvolvimento de plantas de aveia-branca (Avena sativa $\mathrm{L}$.) e a microflora da rizosfera e do rizoplano. Revista Brasileira de Sementes, v. 24, n. 1, p. 237-243, 2002.

SOUSA, M. V. et al. Métodos de inoculação e efeitos de Fusarium oxysporum f. sp. vasinfectum em sementes de algodoeiro. Tropical Plant Pathology, v. 33, n. 1, p. 41-48, 2008. 